\title{
Diversity and functional properties of Lactobacillus plantarum-group strains isolated from Italian cheese products
}

\author{
M. Barbara Pisano • Francesca Patrignani • \\ Sofia Cosentino • M. Elisabetta Guerzoni • \\ Charles M. A. P. Franz • Wilhelm H. Holzapfel
}

Received: 25 January 2010 /Revised: 11 June 2010 / Accepted: 11 June 2010 /

Published online: 2 August 2010

(C) INRA, EDP Siences, 2010

\begin{abstract}
The aim of this study was to characterize dairy Lactobacillus plantarum-group strains on the basis of their phenotypic and genotypic profiles in order to increase the knowledge on the ecology and biodiversity within this wild Lactobacillus group. In addition, their in vitro potential probiotic properties were evaluated with a view to identifying potential interesting applications. Among the strains, both physiological and biochemical characteristics differed noticeably, indicating biodiverse phenotypic differences. Genotyping experiments using randomly amplified polymorphic DNA (RAPD)-PCR with primer M13 also showed a remarkable heterogeneity among the strains and allowed the strains to be grouped into the species L. plantarum and L. pentosus/L. paraplantarum. With regard to probiotic functional characteristics, the L. plantarum strains $31 \mathrm{C}$ and $143 \mathrm{C}$ and the L. plantarum strains 64FS and 61FS, isolated from Caciotta and Fiore Sardo cheeses, respectively, survived simulated gastrointestinal conditions and were considered to be acid and bile
\end{abstract}

This article should be cited as: Pisano M.B. et. al., Diversity and functional properties of Lactobacillus plantarum-group strains isolated from Italian cheese products, Dairy Science \& Technology (2010), doi:10.1051/dst/2010037

\footnotetext{
M. B. Pisano $(\bowtie) \cdot S$. Cosentino

Department of Experimental Biology, Section of Hygiene, University of Cagliari,

Cittadella Universitaria, SS 554, Km 4,5, 09042 Monserrato, CA, Italy

e-mail: barbara.pisano@unica.it

F. Patrignani $\cdot$ M. E. Guerzoni

Department of Food Science, University of Bologna, p.zza Goidanich 60, 47023 Cesena, Italy

C. M. A. P. Franz • W. H. Holzapfel

Department of Safety and Quality of Fruit and Vegetables, Federal Research Institute for Nutrition and Food, Haid-und-Neu-Strasse 9, 76131 Karlsruhe, Germany

W. H. Holzapfel

Handong Global University, School of Life and Food Sciences, Pohang, Gyeongbuk 791-708, South Korea
} 
tolerant. The majority of the strains exhibited antagonistic activity towards Escherichia coli ATCC 43895 and L. sakei DSM 20017, but only one of these strains was found to produce a bacteriocin-like compound. The results of this study suggest the presence of both phenotypic and genotypic variation within the $L$. plantarum group isolated from the two different Italian cheeses. Further investigation and development as potential probiotic strains is required.

\begin{abstract}
摘要 - 意大利干酪中Lactobacillus plantarum 菌群的多样性和功能特性。为了增加对野生 型 乳杆菌(Lactobacillus)菌群的生态学和生物多样性的了解，本文利用表型和基因鉴定法研 究 了意大利干酪 (Italian cheese) 中植物乳杆菌 (Lactobacillus plantarum) 菌群的分布。并通 过 体外实验探讨了这些菌株的潜在益生菌功能特性。结果显示不同菌株的生理和生化特征 完全 不同。以引物 M13 进行 RAPD-PCR 实验, 发现不同菌株之间的RAPD图谱有显著差 异, 可以 归为干酪乳杆菌 (L. plantarum), 戊糖乳杆菌 (L. pentosus) 和副干酪乳杆菌 (L. paraplantarum)。关于益生菌的功能特性, 源于Caciotta 干酪中的菌株 L. plantarum 31C 和 143C 及 Fiore Sardo 干酪中的 L. plantarum 64FS 和 61FS 菌株都能在模拟肠道环境中 存活, 意味着这些菌 是耐酸和耐胆汁的。干酪中大部分乳杆菌能抑制大肠杆菌ATCC 43895 和 L. sakei DSM 20017 的生长, 但只有一株菌能产生类细菌素的化合物。结果显示表型和基因鉴 定法均能得到两种 不同意大利干酪中植物乳杆菌群的变化。但是其中的潜在益生菌特性则 需要进一步研究。
\end{abstract}

Keywords Lactobacillus plantarum-group · Caciotta cheese · Fiore Sardo cheese · RAPD-PCR · probiotics

关键词 植物乳杆菌群·Caciotta 干酪·Fiore Sardo 干酪·RAPD-PCR · 益生菌

\title{
1 Introduction
}

The genus Lactobacillus is the largest and, perhaps, the most important genus of lactic acid bacteria, representatives of which play a significant role in the human and animal gastrointestinal tract. Moreover, lactobacilli represent one of the major groups involved in desirable fermentation and contribute to food preservation (Coeuret et al. 2003; Holzapfel 2002).

Within the genus Lactobacillus, L. plantarum is a heterogeneous and versatile species that is encountered in a variety of environmental niches, including dairy, meat and many vegetable or plant fermentations. It is one of a group of mesophilic lactobacilli which may become the dominant microorganism in several types of cheese during ripening (Hynes et al. 2003; Rantsiou et al. 2008; Sánchez et al. 2005). Its predominance has also been documented in different African traditional fermented milk products such as Ititu (Kasseye et al. 1991), Gari (Kostinek et al. 2005b) and Kule naoto (Mathara et al. 2004, 2008).

Lactobacillus plantarum strains are characterized by a highly variable phenotype (Mathara et al. 2008) and a relatively large genome (Kleerebezem et al. 2003), which explain their wide distribution and high interstrain diversity. This, unfortunately, complicates their discrimination from the closely related species of L. pentosus and L. paraplantarum on the basis of phenotypic methods alone (Kostinek et al. 2005b). Species-specific primers were designed to obtain a clear distinction among these species but unfortunately they did not guarantee a sufficient level of specificity (Berthier and Erlich 1998; Torriani et al. 2001). Determination of the diversity of the 
L. plantarum population to strain level necessitates the use of a rapid method suitable for handling large number of isolates. Randomly amplified polymorphic DNA (RAPD) analysis has been used to investigate the diversity of $L$. plantarum strains isolated from different sources (Spano et al. 2002) to both the species or the strain level.

Lactobacillus plantarum also has a role as a potential probiotic organism. Even though definitions of probiotic bacteria originally included intestinal source strains, currently, many non-starter lactic acid bacteria, some non-lactics (Holzapfel et al. 1998) and also some yeasts, especially Saccharomyces boulardii, are used in commercial probiotic products. For this reason, the search for strains which show resistance to biological barriers of the human gastrointestinal tract, and which possess physiological characteristics compatible with probiotic properties may eventually lead to the finding of new probiotic strains for functional dairy foods.

Therefore, this work aimed to study the diversity of L. plantarum-group strains, isolated from artisanal dairy products by phenotypic characterization and RAPDPCR techniques and to evaluate their potential probiotic properties.

\section{Materials and methods}

\subsection{Bacterial strains and growth conditions}

A total of 57 strains phenotypically assigned to the L. plantarum-group were examined in this study. Thirty-two strains were isolated from Fiore Sardo, a PDO raw milk cheese (Pisano et al. 2007) and twenty-five from Caciotta cheeses obtained from raw, pasteurized or high-pressure-homogenized (HPH) cow milk (Lanciotti et al. 2006). The strains were grown in de Man, Rogosa and Sharpe (MRS) broth (Merck, Darmstadt, Germany) at $37^{\circ} \mathrm{C}$ for $24 \mathrm{~h}$. Pure cultures were obtained by streaking out onto MRS agar (Merck, Darmstadt, Germany). Stock cultures were stored at $-18{ }^{\circ} \mathrm{C}$ in MRS broth containing 15\% glycerol. Working cultures were prepared from frozen stocks and were transferred at least twice in MRS broth before use in experiments.

\subsection{Phenotypic characterization}

Growth at $15{ }^{\circ} \mathrm{C}$ and $45^{\circ} \mathrm{C}$ was determined in MRS broth after incubation for 7 and 2 days, respectively. Salt tolerance was determined using MRS broth containing $6.5 \% \mathrm{NaCl}$ incubated for $48 \mathrm{~h}$ at $37^{\circ} \mathrm{C}$. $\mathrm{CO} 2$ production from glucose, hydrolysis of arginine and determination of the presence of meso-di-aminopimelic acid ( $m$-DAP) in the cell wall were determined according to the chromatographic method by using thin-layer chromatography on cellulose plates (Schillinger and Lücke 1987).

Carbohydrate fermentation patterns were determined in microtiter plates as previously described (Jaine-Williams 1976). Sugars tested during growth at $30{ }^{\circ} \mathrm{C}$ for $48 \mathrm{~h}$ included amygdalin, arabinose, cellobiose, esculin, galactose, glucose, lactose, maltose, mannitol, melezitose, melibiose, raffinose, rhamnose, ribose, salicin, sorbitol, sucrose, trehalose and xylose (Merck, Darmstadt, Germany). The type strains L. plantarum ATCC 20174 T, L. plantarum ATCC 8014, L. paraplantarum LTH $5200 \mathrm{~T}$ and L. pentosus DSM 20314 T were included as reference species. Strain ATCC 8014 was received from Agrotechnical Research Institute, Wageningen, The 
Netherlands. The production of both $\mathrm{D}(-)$ and $\mathrm{L}(+)$ lactate enantiomers from glucose fermentation was enzymatically determined in the cell-free supernatant from $24 \mathrm{~h}$ cultures in MRS broth, using an UV enzymatic kit (Boehringer-Mannheim, Mannheim, Germany).

\subsection{Genotypic characterization}

\subsubsection{DNA isolation}

Total genomic DNA was isolated using the guanidium thiocyanate extraction method (Pitcher et al. 1989), as modified for Gram-positive microorganisms (Björkroth \& Korkeala 1996).

\subsubsection{Genetic fingerprinting by RAPD-PCR}

Randomly amplified polymorphic DNA (RAPD)-PCR analysis was used to determine the heterogeneity of the L. plantarum strains and to compare genotypes isolated from different sources. L. plantarum ATCC 8014, L. paraplantarum LTH 5200 T, L. arizonensis DSM 13273 T, L. pentosus DSM 20314 T, L. plantarum DSM 20174 T, L. plantarum CNRZ 1228 and L. plantarum BFE 617 type or reference strains were included in the study for comparison purposes. Amplification was performed in a Primus 96 plus Thermal Cycler (MWG Biotech, Ebersberg, Germany) using primer M13 (5'-GAG GGT GGC GGT TCT-3') (Andrighetto et al. 2001). PCR was performed in $50 \mu \mathrm{L}$ reaction mixture volumes each containing $250 \mu \mathrm{mol} \cdot \mathrm{L}^{-1} \mathrm{dNTPs}, 1 \mu \mathrm{mol} \cdot \mathrm{L}^{-1}$ primer, $2.5 \mathrm{mmol} \cdot \mathrm{L}^{-1} \mathrm{MgCl}_{2}, 1.25 \mathrm{U}$ of Taq DNA polymerase (Amersham, Buckinghamshire, UK), 1 X PCR buffer and $10 \mu \mathrm{L}$ of template DNA. PCR products were analyzed by gel electrophoresis on $1.8 \%(\mathrm{w} / \mathrm{v})$ agarose gels using $1 \mathrm{X}$ TBE buffer. The gels were run for $16 \mathrm{~h}$ at $48 \mathrm{~V}$, stained with ethidium bromide and visualized with UV transilluminator. Photographs of RAPD-PCR gels were scanned and the electrophoretic profiles were analyzed by BioNumerics (version 2.5) software (Applied Maths, Sint-Martens-Latem, Belgium). Grouping of the RAPD-PCR fingerprints was performed by means of the Pearson product-moment correlation coefficient $(r)$ and UPGMA clustering algorithm.

\subsection{Antagonistic activity}

The agar spot test was used for monitoring the antagonistic activity of the tested strains against L. sakei subsp. sakei DSM $20017^{\mathrm{T}}$ and E. coli ATCC 43895 (Schillinger and Lücke 1989). In addition, the agar spot test method used by Uhlman et al. (Uhlman et al. 1992) was further used in order to test the activity of cell-free-neutralized supernatants. Briefly, cell-free-neutralized supernatants were obtained from overnight producer cultures grown in MRS broth at $37^{\circ} \mathrm{C}$. After centrifuging the culture $(7,200 \times \mathrm{g}$, $10 \mathrm{~min}$ ), the supernatants were neutralized with sterile $5 \mathrm{~mol} \cdot \mathrm{L}^{-1} \mathrm{NaOH}$ and then boiled for $5 \mathrm{~min}$ to inactivate residual viable cells. The supernatants were tested against the same indicator strains used above. In order to establish the proteinaceous nature of the inhibitory compounds, sensitivity to the proteolytic enzyme protease (Sigma, Milan, 
Italy) of the cell-free supernatants was tested. Samples of $100 \mu \mathrm{L}$ were incubated for $2 \mathrm{~h}$ in the presence of $1 \mathrm{mg} \cdot \mathrm{mL}^{-1}$ (final concentration) enzyme and tested for antimicrobial activity by using the agar spot testmethod as described before.

\subsection{Survival under gastric and intestinal conditions}

\subsubsection{Acid resistance and bile tolerance: preliminary selection of strains}

Acid resistance was determined according to the method described by Hydrominus et al. (Hydrominus et al. 2000). The Lactobacillus overnight cultures were centrifuged $(13,000 \times \mathrm{g}, 4 \mathrm{~min})$, resuspended in MRS broth adjusted to $\mathrm{pH} 2.5$ and 2.0 with $5 \mathrm{~mol} \mathrm{~L}^{-1} \mathrm{HCl}$ and cultured for $2 \mathrm{~h}$ at $37^{\circ} \mathrm{C}$. The survival was evaluated by determining viable counts after 0 and $2 \mathrm{~h}$ of incubation at $37{ }^{\circ} \mathrm{C}$ by plate counting on MRS agar (incubation for $48 \mathrm{~h}$ at $37{ }^{\circ} \mathrm{C}$, anaerobic conditions). Bile salt tolerance was assessed by resuspending cells in MRS broth ( $\mathrm{pH} \mathrm{6.5,} 2.5$ and 2.0) containing $0.3 \%(\mathrm{w} / \mathrm{v})$ Oxgall (Sigma, Munich, Germany), and determining their growth at $37{ }^{\circ} \mathrm{C}$ for $48 \mathrm{~h}$. The positive control comprised inoculated MRS broth without bile salts.

\subsubsection{Response in simulated stomach duodenum-passage}

To evaluate the ability of selected strains to survive the gastrointestinal barriers, a simulated stomach duodenum-passage (SSDP) test was performed similar to that of Vizoso Pinto et al. (2006). Overnight cultures of the tested strains were diluted (1:10) in quarterstrength Ringer solution and their absorbance was determined at $600 \mathrm{~nm}$. The strains were inoculated to a final concentration of $2 \times 10^{8}$ cell $\mathrm{mL}^{-1}$ in $10 \mathrm{~mL}$ of MRS broth adjusted to $\mathrm{pH} 3.0$ with $5 \mathrm{~mol} \cdot \mathrm{L}^{-1} \mathrm{HCl}$. Initial viable counts were determined on MRS agar (incubated at $37{ }^{\circ} \mathrm{C}$ for 24 $48 \mathrm{~h}$ under anaerobic conditions). After $1 \mathrm{~h}, 4 \mathrm{~mL}$ of $10 \%$ Oxgall (Sigma) and $17 \mathrm{~mL}$ of synthetic duodenal secretion ( $\mathrm{pH} 7.4$ ), consisting of $6.4 \mathrm{~g} \cdot \mathrm{L}^{-1} \mathrm{NaHCO}_{3}$, $0.239 \mathrm{~g} \cdot \mathrm{L}^{-1} \mathrm{KCl}$ and $1.28 \mathrm{~g} \cdot \mathrm{L}^{-1} \mathrm{NaCl}$ (Merck, Darmstadt, Germany), were added to the cell suspensions contained in the flask. After 1, 2 and $3 \mathrm{~h}$ of incubation at $37{ }^{\circ} \mathrm{C}$, the survival rate was determined by the plate method at the conditions described above.

\section{Results and discussion}

\subsection{Phenotypic characterization of L. plantarum-group strains}

All 57 strains were presumptively assigned to the L. plantarum-group on the basis of the phenotypical tests (Table 1). These strains were all catalase-negative, facultatively heterofermentative rods, which contained $m$-DAP in their cell walls and which produced both the D and L lactate enantiomers. Moreover, all were able to grow at $15^{\circ} \mathrm{C}$. None of the strains from Fiore Sardo cheese was able to hydrolyze arginine, while one strain from Caciotta cheese was positive for this trait. Seven strains from Caciotta cheese were able to grow at $45^{\circ} \mathrm{C}$. Despite their mesophilic 
Table 1 Physiological and biochemical characteristics of the L. plantarum group strains isolated from the two different cheeses.

\begin{tabular}{|c|c|c|c|c|c|}
\hline \multirow[t]{2}{*}{ Characteristics } & & \multicolumn{2}{|c|}{ Fiore Sardo strains } & \multicolumn{2}{|c|}{ Caciotta strains } \\
\hline & & \multicolumn{2}{|c|}{ No. and $\%$ of positive strains } & \multicolumn{2}{|c|}{ No. and $\%$ of positive strains } \\
\hline$m$-DAP & & 32 & 100 & 25 & 100 \\
\hline \multirow[t]{3}{*}{ Growth at } & $15^{\circ} \mathrm{C}$ & 32 & 100 & 25 & 100 \\
\hline & $45^{\circ} \mathrm{C}$ & 0 & 0 & 7 & 28 \\
\hline & $6.5 \% \mathrm{NaCl}$ & 32 & 100 & 25 & 100 \\
\hline Hydrolysis of Arginine & & 0 & 0 & 1 & 4 \\
\hline Hydrolysis of Aesculin & & 32 & 100 & 25 & 100 \\
\hline \multirow[t]{17}{*}{ Fermentation of: } & Amygdaline & 29 & 90.6 & 25 & 100 \\
\hline & L-arabinose & 32 & 100 & 16 & 64 \\
\hline & Cellobiose & 29 & 90.6 & 25 & 100 \\
\hline & Galactose & 32 & 100 & 25 & 100 \\
\hline & Lactose & 32 & 100 & 25 & 100 \\
\hline & Maltose & 32 & 100 & 25 & 100 \\
\hline & Melezitose & 5 & 15.6 & 21 & 84 \\
\hline & Melibiose & 32 & 100 & 21 & 84 \\
\hline & Raffinose & 15 & 46.8 & 4 & 16 \\
\hline & Ribose & 32 & 100 & 21 & 84 \\
\hline & Salicine & 32 & 100 & 25 & 100 \\
\hline & Sorbitol & 12 & 37.5 & 21 & 84 \\
\hline & Sucrose & 5 & 15.6 & 25 & 100 \\
\hline & Trehalose & 32 & 100 & 25 & 100 \\
\hline & Xylose & 3 & 9.4 & 7 & 28 \\
\hline & Mannitol & 32 & 100 & 25 & 100 \\
\hline & Amygdaline & 32 & 100 & 25 & 100 \\
\hline Lactate isomer produced & & \multicolumn{2}{|c|}{ DL (all strains tested) } & \multicolumn{2}{|c|}{ DL (all strains tested) } \\
\hline
\end{tabular}

aptitude, some $L$. plantarum strains have already been reported to grow at this high temperature (Kostinek et al. 2008; Stiles and Holzapfel 1997).

With respect to the sugar fermentation patterns, it was noted that a high number of strains from both types of cheese were able to ferment pentoses such as ribose and L-arabinose, which is consistent with their characterization as facultatively heterofermentative $L$. plantarum strains. In contrast, some variations were also observed between the strains stemming from the two different cheeses. In particular, a very low percentage $(15.6 \%)$ of strains from Fiore Sardo cheese was able to ferment melezitose and sucrose when compared with the $84 \%$ melezitose-positive and $100 \%$ sucrose-positive strains from Caciotta. Raffinose was fermented by $46.8 \%$ and $16 \%$ of strains isolated from Fiore Sardo and Caciotta cheeses, respectively. Furthermore, 10 strains (three from Fiore Sardo and seven from Caciotta) fermented xylose, which is a typical characteristic of $L$. pentosus strains. 


\subsection{Genotypic characterization}

The RAPD profiles of the cheese strains generated with primer M13 produced the UPGMA dendrogram shown in Fig. 1. RAPD-PCR was done in duplicate for some reference strains to determine the reproducibility of the method. Cluster analysis showed correlation values of $\mathrm{r}=90 \%, 87 \%$ and $80 \%$ for the duplicates of the strains L. paraplantarum LTH 5200 T, L. plantarum ATCC 8014 and L. arizonensis DSM 13273 T, respectively, and $77.8 \%$ correlation between the duplicates of the strain L. pentosus DSM 20314 ${ }^{\mathrm{T}}$. For L. pentosus DSM 20314 three separate profiles were actually done, as the correlation value obtained initially with two fingerprint sets of the same type strain was considered low. A third fingerprint clustered better one of the initial two prints at $77.8 \%$ and we took this value as the cutoff value for possible clonal relationships. A high diversity was revealed among the strains tested according to the heterogeneity in the fingerprint patterns obtained (Fig. 1). The strains were grouped in four clusters (I, II, III and IV) at $\mathrm{r}=15 \%$. Cluster I included the L. plantarum type strains DSM 20174 ${ }^{\mathrm{T}}$, L. plantarum CNRZ 1228, L. plantarum ATCC 8014 from duplicate DNA extractions, L. plantarum BFE 617, 16 isolates from Caciotta cheese and 14 from Fiore Sardo cheese. Cluster II included 17L. plantarumgroup strains isolated from Fiore Sardo and three strains from Caciotta cheese. In addition, this cluster also contained the type strain of L. arizonensis DSM $13273^{\mathrm{T}}$. The species L. arizonensis was previously rejected by Kostinek et al. (2005a) as a later heterotypic synonym of $L$. plantarum. Cluster III included the type strains of $L$. pentosus DSM $20314^{\mathrm{T}}$ and L. paraplantarum LTH $5200^{\mathrm{T}}$, three strains from Caciotta and one from Fiore Sardo. Cluster IV consisted of three strains from Caciotta cheese. Four out of seven strains included in these later two clusters were able to ferment xylose, a typical feature of $L$. pentosus species.

The RAPD analysis also revealed the occurrence of several subclusters poorly related to each other (similarity 30\%), confirming the high genetic diversity of L. plantarum previously reported by other authors (Kostinek et al. 2008; Sánchez et al. 2005). Some strains had very similar fingerprinting patterns and showed a correlation coefficient $>77.8 \%$. This suggested that these strains could be multiple isolates of the same strain, since they were isolated from the same cheese. Although most subclusters were mainly constituted by strains isolated from Fiore Sardo or Caciotta cheese, no correlation between grouping and origin of the strains was found and RAPD types showing a high level of similarity were isolated from the two cheeses. For example, strains 75C, 64FS and 32FS clustered together at $83 \%$ similarity. Similar findings were obtained for strains $57 \mathrm{C}, 37 \mathrm{C}$ and $66 \mathrm{FS}$.

\subsection{Antagonistic activity}

Most of the strains tested showed an inhibitory activity toward E. coli and L. sakei DSM 20017 (Table 2), most likely due to the production of organic acids. Only the supernatant of strain $143 \mathrm{C}$ was able to inhibit E. coli after neutralization and heating suggesting a possible production of a heat stable bacteriocin (data not shown). Complete inactivation in antimicrobial activity was observed after treatment of the cell-free supernatant with protease confirming its proteinaceous nature. 


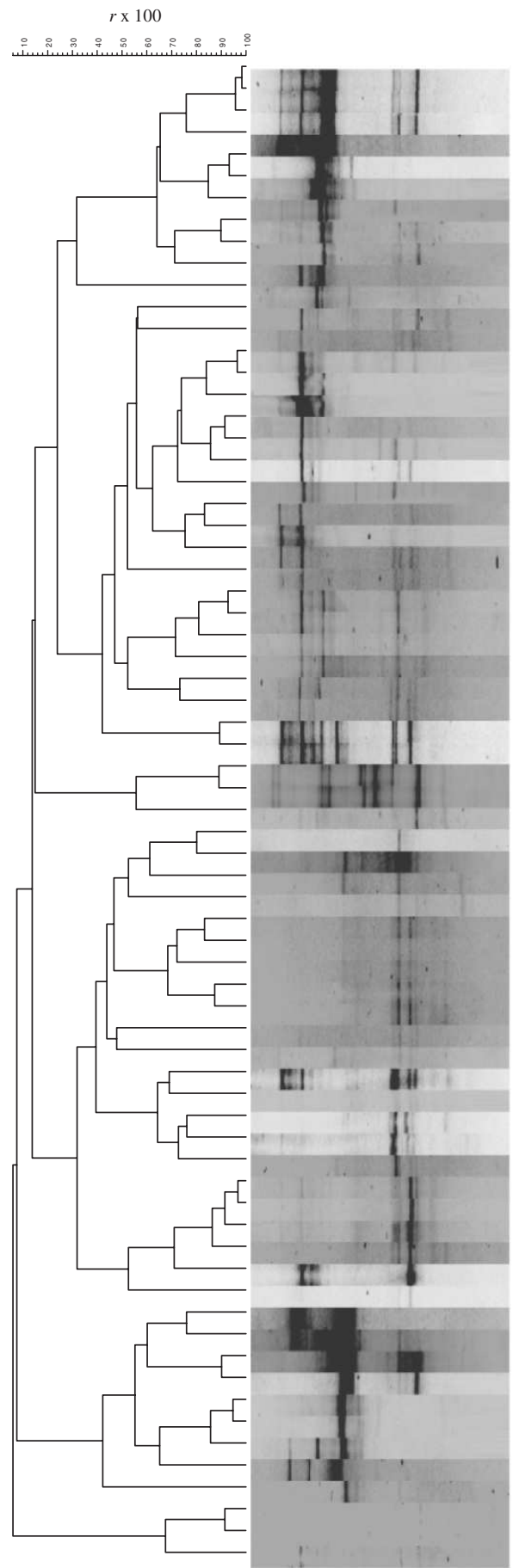

Strain Nr.

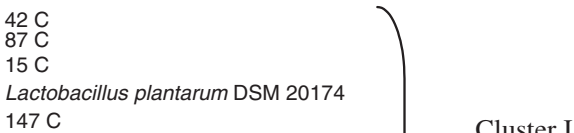

$18 \mathrm{C}$

Lactobacillus plantarum CNRZ 1228

$35 \mathrm{C}$

$31 \mathrm{C}$

$45 \mathrm{FS}$

$58 \mathrm{C}$

$82 \mathrm{C}$

$68 \mathrm{FS}$

$75 \mathrm{C}$

$64 \mathrm{FS}$

$32 \mathrm{FS}$

$26 \mathrm{C}$

$63 \mathrm{C}$

$186 \mathrm{C}$

Lactobacillus plantarum BFE 617

$26 \mathrm{FS}$

7 FS

27 a FS

6 FS

3 FS

4 FS

$34 \mathrm{FS}$

$25 \mathrm{FS}$

$52 \mathrm{FS}$

$61 \mathrm{FS}$

$145 \mathrm{C}$

$67 \mathrm{C}$

Lactobacillus plantarum ATCC 8014

Lactobacillus plantarum ATCC 8014

$68 \mathrm{C}$

Lactobacillus arizonensis DSM 13273

Lactobacillus arizonensis DSM 13273b

68 FS

$36 \mathrm{FS}$

$8 \mathrm{FS}$

$9 \mathrm{FS}$

$27 \mathrm{FS}$

$53 \mathrm{FS}$

$65 \mathrm{FS}$

$10 \mathrm{FS}$

$45 \mathrm{C}$

$1 \mathrm{FS}$

$12 \mathrm{FS}$

2 FS

$62 \mathrm{FS}$

$21 \mathrm{C}$

$43 \mathrm{FS}$

$60 \mathrm{FS}$

$50 \mathrm{FS}$

$54 \mathrm{FS}$

3-13 FS

$143 \mathrm{C}$

Lactobacillus pentosus DSM 20314

Lactobacillus pentosus DSM 20314b Lactobacillus paraplantarum LTH $5200 \mathrm{~b}$

Lactobacillus paraplantarum LTH 5200

$57 \mathrm{C}$

$37 \mathrm{C}$

66 FS

Lactobacillus pentosus DSM 20314

$184 \mathrm{C}$

$70 \mathrm{C}$

$84 \mathrm{C}$

$83 \mathrm{C}$

Cluster II

Fig. 1 Dendrogram obtained by UPGMA of correlation value $r$ of RAPD-PCR fingerprint patterns with primers M13 of facultatively heterofermentative L. plantarum group isolates from Fiore Sardo and Caciotta cheese and reference strains 
Table 2 Antagonistic activity of L. plantarum strains isolated from Fiore Sardo and Caciotta cheeses

\begin{tabular}{|c|c|c|}
\hline \multirow[t]{2}{*}{ Strains tested } & \multicolumn{2}{|c|}{ Antimicrobial activity against } \\
\hline & E. coli ATCC 43895 & L. sakei DSM 20017 \\
\hline \multicolumn{3}{|l|}{ Fiore Sardo cheese } \\
\hline $1 \mathrm{FS} ; 3-13 \mathrm{FS} ; 52 \mathrm{FS}$ & +++ & + \\
\hline $10 \mathrm{FS} ; 3 \mathrm{FS}$ & +++ & ++ \\
\hline $25 \mathrm{FS}$ & +++ & - \\
\hline $\begin{array}{l}\text { 45FS; 27FS; 6FS; 32FS; 53FS; 43FS; } \\
\text { 61FS; 36FS; 81FS; 65FS; 50FS; 54FS }\end{array}$ & ++++ & ++ \\
\hline $2 \mathrm{FS} ; 8 \mathrm{FS}$ & - & - \\
\hline $12 \mathrm{FS}$ & ++++ & - \\
\hline 26FS; 60FS; 9FS & ++++ & + \\
\hline 7FS & +++ & - \\
\hline 64FS; 66FS; 34FS & ++++ & ++ \\
\hline $4 \mathrm{FS}$ & +++++ & + \\
\hline $68 \mathrm{FS} ; 27 \mathrm{FS} ; 62 \mathrm{FS}$ & +++++ & ++ \\
\hline \multicolumn{3}{|l|}{ Caciotta cheese } \\
\hline $37 \mathrm{C}$ & ++ & ++ \\
\hline $18 \mathrm{C}$ & ++ & + \\
\hline $75 \mathrm{C}$ & +++ & + \\
\hline $42 \mathrm{C}$ & +++ & ++ \\
\hline $84 \mathrm{C} ; 87 \mathrm{C}$ & - & - \\
\hline $\begin{array}{l}15 \mathrm{C} ; 147 \mathrm{C} ; 45 \mathrm{C} ; 21 \mathrm{C} ; 82 \mathrm{C} ; 35 \mathrm{C} ; 186 \mathrm{C} ; \\
145 \mathrm{C} ; 67 \mathrm{C} ; 184 \mathrm{C} ; 68 \mathrm{C} ; 57 \mathrm{C} ; 70 \mathrm{C} ; 83 \mathrm{C}\end{array}$ & ++ & - \\
\hline $26 \mathrm{C}$ & ++ & ++ \\
\hline $31 \mathrm{C}$ & + & - \\
\hline $58 \mathrm{C}$ & ++ & ++ \\
\hline $63 \mathrm{C}$ & +++ & - \\
\hline $143 \mathrm{C}$ & +++++ & +++++ \\
\hline
\end{tabular}

Inhibition was scored according to the width of the zone of clearing around the colonies of the test strain according these criteria: clear zone $>8 \mathrm{~mm}(+++++)$; clear zone $8-6 \mathrm{~mm}(++++) ; 4 \mathrm{~mm}<$ clear zone $<6$ $\mathrm{mm}(+++) ; 2 \mathrm{~mm}<$ clear zone $<4 \mathrm{~mm}(++) ; 0.5 \mathrm{~mm}<$ clear zone $<2 \mathrm{~mm}(+)$.

\subsection{Resistance to simulated gastrointestinal conditions}

Results suggested that generally these strains had a good resistance to $\mathrm{pH} 2.5$ (> $75 \%$ of strains) (data not shown). On the contrary, only few strains were able to survive after exposure to $\mathrm{pH} 2.0$ for $2 \mathrm{~h}$. These included strains $31 \mathrm{C}, 184 \mathrm{C}$ and $143 \mathrm{C}$ from Caciotta cheese and the strains 10FS, 61FS, 64FS and 50FS from Fiore Sardo cheese (Table 3). All the strains grown in MRS broth at $\mathrm{pH} 2.0$ and 2.5 were reinoculated in MRS broth in the presence of $0.3 \%(\mathrm{w} / \mathrm{v})$ bile salts and their growth was evaluated after 24 and $48 \mathrm{~h}$ of incubation at $37^{\circ} \mathrm{C}$ (data not shown). Stresses to 
Table 3 Tolerance of L. plantarum group strains to $\mathrm{pH} 2.0$ for $2 \mathrm{~h}$ at $37^{\circ} \mathrm{C}$

\begin{tabular}{lcc}
\hline Strains $^{\mathrm{a}}$ & $\begin{array}{l}\text { Initial count } \\
(\log 10 \mathrm{CFUs} \cdot \mathrm{mL})\end{array}$ & $\begin{array}{l}\text { Bacterial counts after } 2 \mathrm{~h} \text { incubation at } 37^{\circ} \mathrm{C} \\
\text { in MRS broth at } \mathrm{pH} 2.0(\log 10 \mathrm{CFUs} \cdot \mathrm{mL})\end{array}$ \\
\hline $10 \mathrm{FS}$ & 9.34 & 4.48 \\
$64 \mathrm{FS}^{\mathrm{b}}$ & 9.00 & 5.54 \\
$61 \mathrm{FS}^{\mathrm{b}}$ & 8.90 & 4.25 \\
$50 \mathrm{FS}$ & 8.98 & 4.55 \\
$31 \mathrm{C}^{\mathrm{b}}$ & 9.68 & 5.14 \\
$184 \mathrm{C}$ & 8.30 & 3.39 \\
$143 \mathrm{C}^{\mathrm{b}}$ & 8.90 & 4.47 \\
\hline
\end{tabular}

${ }^{a}$ The remainder of strains tested in this study exhibited a viability lower than $4 \log \mathrm{CFU} \cdot \mathrm{mL}^{-1}$ (data not shown). ${ }^{\mathrm{b}}$ Strains resistant to $0.3 \%$ bile.

microorganisms begin in the stomach, which has a $\mathrm{pH}$ between 1.5 and 3.0, and in the upper intestine which contains bile. Survival at $\mathrm{pH} 3.0$ for $2 \mathrm{~h}$ and at a bile concentration of $1000 \mathrm{mg} \cdot \mathrm{L}^{-1}$ is considered optimal acid and bile tolerance for potentially probiotic strains (Usman 1999). The L. plantarum-group strains 31C and $143 \mathrm{C}$, isolated from Caciotta cheese manufactured from raw and HPH treated milk, respectively, and 64FS and 61FS, isolated from Fiore Sardo, seem particularly interesting, because they were able to survive $2 \mathrm{~h}$ incubation at $\mathrm{pH} 2.0$ and in the presence of $0.3 \%$ bile. The same strains were also able to survive to SSDP, confirming their good adaptation capabilities (Table 4).

Table 4 Survival of Lactobacillus strains isolated from Fiore Sardo and Caciotta cheese in simulated stomach duodenum-passage at $37{ }^{\circ} \mathrm{C}$. Results are means of three independent experiments

\begin{tabular}{|c|c|c|c|c|c|}
\hline \multicolumn{5}{|c|}{ Viable cell numbers $\left(\log _{10} \mathrm{CFUs} \cdot \mathrm{mL}^{-1}\right)$} & \multirow{2}{*}{$\begin{array}{l}\begin{array}{l}\text { Growth } \\
\text { (after } 24 \mathrm{~h})\end{array} \\
\end{array}$} \\
\hline \multicolumn{5}{|c|}{ Time (h) of incubation in simulated stomach-duodenum juice } & \\
\hline Strain & $0 \mathrm{~h}$ & $1 \mathrm{~h}$ & $2 \mathrm{~h}$ & $3 \mathrm{~h}$ & $24 \mathrm{~h}$ \\
\hline \multicolumn{5}{|c|}{ Fiore Sardo cheese } & \\
\hline 64FS & $8.87 \pm 0.04$ & $6.39 \pm 0.13$ & $6.39 \pm 0.07$ & $6.34 \pm 0.16$ & W \\
\hline $61 \mathrm{FS}$ & $8.98 \pm 0.04$ & $6.54 \pm 0.33$ & $7.03 \pm 0.60$ & $6.27 \pm 0.26$ & + \\
\hline $50 \mathrm{FS}$ & $8.00 \pm 0.06$ & $6.73 \pm 0.06$ & $6.60 \pm 0.05$ & $6.30 \pm 0.06$ & - \\
\hline $10 \mathrm{FS}$ & $8.23 \pm 0.04$ & $6.39 \pm 0.13$ & $5.99 \pm 0.12$ & $6.05 \pm 0.21$ & - \\
\hline \multicolumn{5}{|c|}{ Caciotta cheese } & \\
\hline $143 \mathrm{C}$ & $8.14 \pm 0.30$ & $7.10 \pm 0.35$ & $6.81 \pm 0.15$ & $6.00 \pm 0.30$ & + \\
\hline $31 \mathrm{C}$ & $8.09 \pm 0.15$ & $6.80 \pm 0.20$ & $5.54 \pm 0.25$ & $4.90 \pm 0.20$ & + \\
\hline $184 \mathrm{C}$ & $8.13 \pm 0.25$ & $5.05 \pm 0.05$ & - & - & - \\
\hline
\end{tabular}

$\mathrm{W}=$ very weak, $+=$ growth detected, $-=$ no growth detected. 


\section{Conclusion}

This study is another contribution to the knowledge on the ecology and biodiversity of strains belonging to the L. plantarum group that were isolated from two different Italian cheeses. Phenotypic and genotypic characterization methods were used to study the diversity among these strains. Genotyping data obtained by RAPDPCR analysis confirmed the previously observed high degree of heterogeneity of L. plantarum strains, and allowed to discriminate between the phenotypically closely related species $L$. plantarum and L. pentosus/L. paraplantarum. The in vitro study of some functional characteristics related to probiotic properties allowed to screen some L. plantarum group strains possessing good potential for further studies on their probiotic capacity. Clearly, to select strains for use as starter cultures or as probiotic requires more in vitro and in vivo trials. This study does, however, allow a pre-selection of potentially interesting cultures which can be further investigated for their probiotic activity.

Acknowledgements The authors are particularly grateful to Frau E. Lubecki and Dr J. Maina Mathara for their technical support and to all the staff of the BFEL Institute.

\section{References}

Andrighetto C, Knijff E, Lombardi A, Torriani S, Vancanneyt M, Kersters K, Swings J, Dellaglio F (2001) Phenotypic and genetic diversity of enterococci isolated from Italian cheeses. J Dairy Res 68:303-316

Berthier F, Erlich SD (1998) Rapid species identification within two groups of closely related lactobacilli using PCR primers that target the 16 S/23 S rRNA spacer region. FEMS Microbiol Lett 161:97-106

Björkroth J, Korkeala H (1996) Evaluation of Lactobacillus sake contamination in vacuumpackage sliced cooked meat products by ribotyping. J Food Prot 59:398-401

Coeuret V, Dubernet S, Bernardeau M, Gueguen M, Vernoux JP (2003) Isolation, characterization and identification of lactobacilli focusing mainly on cheeses and other dairy products. Lait 83:269-306

Holzapfel WH (2002) Appropriate starter culture technologies for small-scale fermentation in developing countries. Int J Food Microbiol 75:197-212

Holzapfel WH, Haberer P, Snel J, Schillinger U, Huis in't Veld JH (1998) Overview of gutflora and probiotics. Int J Food Microbiol 41:85-101

Hydrominus B, Le Marrec C, Hadj Sassi A, Deschamps A (2000) Acid and bile tolerance of sporeforming lactic acid bacteria. Int J Food Microbiol 61:193-197

Hynes E, Bach C, Lamberet G, Ogier JC, Son O, Delacroix-Buchet A (2003) Contribution of starter lactococci and adjunct lactobacilli to proteolysis, volatile profiles and sensory characteristics of washed-curd cheese. Lait 83:31-43

Jaine-Williams DJ (1976) The application of miniaturized methods for characterization of various organisms isolated from the animal gut. J Appl Bacteriol 40:189-200

Kasseye T, Simpson BK, Smith JP, O’Connor CB (1991) Chemical and microbiological characteristics of Ititu. Milchwissenschaft 46:649-653

Kleerebezem M., Boekhorst J., van Kranenburg R., Molenaar D., Kuipers O.P., Leer R., Tarchini R., Peters S. A., Sandbrink H.M., Fiers M.W.E.J., Stiekema W., Klein Lankhorst R.M., Bron P.A., Hoffer S.M., Nierop Groot M.N., Kerkhoven R., de Vries M., Ursing B., de Vos W.M., Siezen R.J., Complete genome sequence of Lactobacillus plantarum WCFS1, Proc. Natl. Acad. Sci. USA 100 (2003) 1990-1995.

Kostinek M, Pukall R, Rooney AP, Schillinger U, Hertel C, Holzapfel WH, Franz CMAP (2005a) Lactobacillus arizonensis is a later heterotypic synonym of Lactobacillus plantarum. Int J Syst Evol Microbiol 55:2485-2489

Kostinek M, Specht I, Edward VA, Schillinger U, Hertel C, Holzapfel WH, Franz CMAP (2005b) Diversity and technological properties of predominant lactic acid bacteria from fermented cassava used for the preparation of Gari, a traditional African food. Syst Appl Microbiol 28:527-540 
Kostinek M, Ban-Koffi L, Ottah-Atikpo M, Teniola D, Schillinger U, Holzapfel WH, Franz CMAP (2008) Diversity of predominant lactic acid bacteria associated with cocoa fermentation in Nigeria. Curr Microbiol 56:306-314

Lanciotti R, Vannini L, Patrignani F, Iucci L, Vallicelli M, Ndagijimana M, Guerzoni ME (2006) Effect of high pressure homogenization of milk on cheese yield and microbiology, lipolysis and proteolysis during ripening of Caciotta cheese. J Dairy Res 73:216-226

Mathara JM, Schillinger U, Kutima PM, Mbugua SK, Holzapfel WH (2004) Isolation, identification and characterization of dominant microorganisms of Kule naoto: the Maasai traditional fermented milk in Kenya. Int J Food Microbiol 64:269-278

Mathara JM, Schillinger U, Kutima PM, Mbugua SK, Guigas C, Franz CMPA, Holzapfel WH (2008) Functional properties of Lactobacillus plantarum strains isolated from Maasai traditional fermented milk products in Kenya. Curr Microbiol 56:315-321

Pisano MB, Fadda ME, Deplano M, Corda A, Casula M, Cosentino S (2007) Characterization of Fiore Sardo cheese manufactured with the addition of autochthonous cultures. J Dairy Res 74:255-261

Pitcher DG, Saunters NA, Owen RJ (1989) Rapid extraction of bacterial genomic DNA with guanidium thiocyanate. Lett Appl Microbiol 8:151-156

Rantsiou K, Urso R, Dolci P, Comi G, Cocolin L (2008) Microflora of Feta cheese from four Greek manufacturers. Int J Food Microbiol 126:36-42

Sánchez I, Seseňa S, Poveda JM, Cabezas L, Palop L (2005) Phenotypic and genotypic characterization of lactobacilli isolated from Spanish goat cheeses. Int J Food Microbiol 102:355-362

Schillinger U, Lücke FK (1987) Identification of lactobacilli from meat and meat products. Food Microbiol 4:199-208

Schillinger U, Lücke FK (1989) Antibacterial activity of Lactobacillus sake isolated from meat. Appl Environ Microbiol 55:1901-1906

Spano G, Beneduce L, Tarantino D, Zapparoli G, Massa S (2002) Characterization of Lactobacillus plantarum from wine must by PCR species-specific, RAPD-PCR. Lett Appl Microbiol 35:370-374

Stiles ME, Holzapfel WH (1997) Lactic acid bacteria of food and their current taxonomy, Review. Int J Food Microbiol 36:1-27

Torriani S, Felis GE, Dellaglio F (2001) Differentiation of Lactobacillus plantarum, L. pentosus, and L. paraplantarum by recA gene sequence analysis and multiplex PCR assay with recA gene-derived primers. Appl Environ Microbiol 67:3450-3454

Uhlman L, Schillinger U, Rupnow JR, Holzapfel WH (1992) Identification and characterization of two bacteriocin-producing strains of Lactococcus lactis isolated from vegetables. Int $\mathrm{J}$ Food Microbiol 16:141-151

Usman HA (1999) Bile tolerance, taurocholate deconjugation, and binding of cholesterol by Lactobacillus gasseri strains. J Dairy Sci 82:243-248

Vizoso Pinto MG, Franz CMAP, Schillinger U, Holzapfel WH (2006) Lactobacillus spp. with in vitro probiotic properties from human faeces and traditional fermented products. Int $\mathrm{J}$ Food Microbiol 109:205-214 